\title{
Food standards and exports: evidence for China
}

\author{
AXEL MANGELSDORF \\ BAM Federal Institute for Materials Research and Testing, Germany, and \\ Technical University Berlin, Chair of Innovation Economics \\ ALBERTO PORTUGAL-PEREZ \\ World Bank \\ JOHN S. WILSON \\ World Bank
}

\begin{abstract}
Using a new database on standards in China, we estimate the impact of voluntary and mandatory standards - either harmonized to international norms or purely domestic - on Chinese food exports. The dataset covers seven Chinese products over the period 1992-2008. We find that standards have a positive effect on China's export performance, as the benefits to standardization in terms of reducing potential information asymmetry and signaling enhance food safety, and quality in foreign markets seem to surpass compliance costs. Our estimation results show that the positive effect of Chinese standards is larger when they are harmonized to international measures. The results suggest that there are clear benefits to China's steps to base their domestic standards and regulations on international measures.
\end{abstract}

\section{Introduction}

China has become a major player in international food exports. The value of Chinese exports in agricultural products more than tripled from 9.7 billion US\$ in 1992 to 30.1 billion US\$ in 2008 as revealed from COMTRADE data. At the same time, food safety issues have been a primary focus of the media due to the recurrence of food safety incidents. ${ }^{1}$ Unsafe food remains a serious threat for Chinese food sales to foreign markets. Indeed, according to the Asian Development Bank (2007), weak regulatory infrastructure and low standards and regulations in China are responsible for recurring incidence of unsafe food and border rejections in foreign markets. For instance, the European Union's Rapid Alert System for Food and Feed (RASFF) reports that Chinese agricultural and food commodities

1 Incidents include infant deaths from fake milk powder in 2004; recurrent food poisonings in Chinese school cafeterias; the sale of meat from animals that were sick or died from illness; and the death of six children in 2008 after consuming milk adulterated with the industrial chemical melamine (Gale and Buzby, 2009). 
reaching the EU were rejected 85 times between 2008 and 2010, the largest number of rejections when compared to other countries. ${ }^{2}$ Continuous incidents of this type cut Chinese producers' revenues due to the rejection and subsequent destruction of Chinese food products. Problems in meeting food safety standards also generate health-related concerns and a drop in foreign consumers' confidence which could act to lower, over time, imports from China.

Generally considered as best practice, international food standards can be a powerful tool in addressing food safety problems. The existence of standards is assumed to be trade promoting compared to a situation where standards are absent (Swann et al., 1996). Standards published by national or international standard setting bodies are commonly described as public goods. Publically available standards based on scientific evidence adopted by domestic firms and referenced in mandatory regulations increase transparency and reduce information asymmetries, especially between producers and foreign customers (Blind and Jungmittag, 2005). Standards can, however, act as barriers to trade. Compliance with standards imposes significant costs to producers in developing countries with constrained financial capacity, and can restrict their ability to export (Czubala et al., 2007; Portugal-Perez et al., 2010).

Chinese authorities implement and introduce mandatory standards - also known as technical regulations - whereas the private sector, often in collaboration with government agencies, develops voluntary standards. China's accession to the World Trade Organization (WTO) in 2001 and its commitment to base domestic regulations and standards on international measures created room for increased harmonization of Chinese standards with international norms. Although compliance with voluntary standards is not mandatory from the legal perspective, commercial practices or consumer demands can often blur the distinction between voluntary and mandatory standards in practice, particularly if voluntary standards are harmonized to international norms.

Does the introduction of mandatory and voluntary standards affect Chinese exports significantly? What is the effect of international harmonization on agricultural products? The aim of this paper is to attempt to answer these questions by assessing econometrically China's development of mandatory and voluntary standards on its exports of agricultural products, using data that link Chinese food standards for seven groups of agricultural products (meat, fish, vegetables, cereals, milk, tea, and sugar) to trade data. The debate over details specific to approaches to harmonization and the structures through which these best occur are beyond the scope of this paper. Our analysis simply addresses the question of whether harmonization effects Chinese exports, and if harmonization does have an impact on exports, does it expand or reduce exports. 
Our research contributes to the existing empirical literature in at least three innovative ways. First, we focus on standards implemented by the exporting country for its produced goods, whereas previous empirical studies mainly focused on standards used by the importing countries. Second, we analyze the impact of standards harmonization in a developing country. Due to data availability, research on the impact of standards harmonization has been so far limited to industrialized countries. To our knowledge, there is no empirical study estimating the impact of national product standards and harmonization in exports from developing countries. Third, our dataset allows differentiating between mandatory and voluntary standards, whereas the differentiation is not possible in previous studies because of data limitation. In addition, each type of standard can be identified as being harmonized to international norms or not.

We use an extended gravity model to examine the impact of food standards in China on its agricultural exports. Although estimates vary slightly across products, the results confirm the export-promoting effect of standards. This is particularly true in regard to mandatory standards. In particular, based on our analysis, we confirm the positive impact of standards harmonization. The impact of an additional standard that is based on international measures, we find, has a larger impact than the marginal impact of purely Chinese domestic standards. Our results provide new evidence on the positive impact of standards, especially standards harmonized to international norms, on export performance.

The rest of the paper is structured as follows. In the next section, we briefly review the literature on the trade effects of standards in general, with a focus on the Chinese case. Section 3 discusses the institutional background and recent developments in China's standardization system for food products. In Section 4, we present our data, descriptive statistics, and empirical strategy, We conduct the empirical analysis and present the effects of standards and regulations in Section 5. Finally, we summarize our results and give with some policy implications, and conclude briefly.

\section{Literature review}

\section{Standards and trade}

Standards can be differentiated by the freedom of choice regarding compliance (Henson, 2004). Mandatory standards are established by public regulators and compliance is obligatory, whereas voluntary standards are often set by standards development organizations, such as the International Organizations of Standardization (ISO) or the Codex Alimentarius Commission, or national standards bodies in a formal process that involves multiple stakeholders, such as industry and trade associations or consumer organizations. Although their application is not legally binding, voluntary standards can become a 'commercial imperative' or 'de facto mandatory', when producers require suppliers to 
comply with such standards. A large part of previous literature on standards and trade do not differentiate between mandatory and voluntary standards (Swann, 2010).

The literature on standards and trade differentiates the impact of standards set in the importing countries from standards set in the exporting country. The former argue that standards in the importing country can act as barriers to trade. With the reduction in tariffs and quotas, governments increasingly use standards to protect their domestic industries. Developing countries are concerned that domestic standards in importing countries - especially in developed countries - increase the cost of compliance and restrict or even prevent market access (Henson and Jaffee, 2008). Empirical studies show that the costs of compliance can be important. For instance, Otsuki et al. (2001) estimate a gravity model to show that stringent standards for maximum allowable contamination in fruit and nuts imposed in the European Union lead to significant export losses for African exporters. At the firm level, Maskus et al. (2004) show that producers from developing countries face substantial investment costs in order to adapt their production processes in compliance with standards in export markets. International trade agreements encourage harmonization of standards across countries. Both the WTO Agreement on Technical Barriers to Trade (TBT) and the Agreement on Sanitary and Phytosanitary Measures (SPS) promote harmonization under the assumption that harmonized standards reduce compliance costs for exporters. Evidence on the trade promoting effect of international harmonization is provided, for instance by Wilson et al. (2003) for beef products. The authors find empirical evidence that if standards were harmonized according to Codex Alimentarius standards, international trade value would rise by more than $50 \%$ compared to the nonharmonized scenario and developing countries would benefit from harmonization of standards. Portugal-Perez et al. (2010) provide similar evidence for electronic products.

Most studies on the impact of standards in the exporting country find a positive trade effect for the exporting country. By providing information on safety levels and signaling quality, standards can help to overcome incomplete or asymmetric information between producers and consumers (Leland, 1979). Hudson and Jones (2003) argue that it is particularly difficult for developing countries to signal the quality of their products to consumers. Developing countries can overcome the reputation problem by applying standards. In this sense, standards serve as quality signals and show consumers that producers in developing countries are able to meet stringent standards and provide safe food products. In a gravity model for agricultural products, Moenius (2006) estimates the impact of domestic and harmonized standards on the exporting country. He finds that the overall effect of domestic standards in the exporting country is to increase trade but the impact of standards harmonization is ambiguous. He argues that the overall effect depends on the balance between reduced compliance costs from harmonization, and the variety reducing effect of harmonization. 


\section{Standards and trade in China}

The literature on the trade effects of standards in China largely focuses on standards in countries importing Chinese products. For instance, Chen et al. (2008) examine the impact of maximum residual standards for pesticides imposed by importing countries on Chinese exports for vegetables and aquatic products. Using a gravity model, the authors find a negative effect of safety standards on imports. Yue et al. (2010) analyze the impact of maximum pesticide residue standards for tea imposed by the European Union. The authors find that the introduction of the stringent EU standard significantly decreases exports from developing countries, including China. They also argue that the WTO should push the EU to harmonize their standards for tea with international Codex Alimentarius standards.

Songa and Chen (2010) differentiate the impact of food regulations in the short run and in the long run. Current food safety regulations notified to the WTO under the WTO SPS Agreement ${ }^{3}$ are used to capture the impact of standards in the short term, whereas two-year lagged regulations capture the impact in the long run. In the short run, regulations in importing countries have a negative effect on Chinese agriculture exports, whereas their impact is positive in the long run. Chinese exporters can cope with foreign regulations in the long run as they increase significantly investment in new testing equipment, training and use voluntary standards to meet certification requirements in order to become competitive. The empirical analysis is, however, limited to aggregated exports and a small number of observations.

Bai et al. (2007) and Jin et al. (2008) confirm that Chinese food producers use increasingly voluntary standards. Based on surveys of Chinese firms, the authors argue that improved product quality and safety, and access to foreign markets are the main incentives to use voluntary standards and apply for certifications. In next section, we briefly introduce the institutional background on standardization in China.

\section{Food safety standardization in China}

A number of government agencies are involved in regulating food safety in China: the Ministry of Agriculture, the Administration of Quality Supervision, Inspection and Quarantine (AQSIQ), the Food and Drug Administration, the Ministry of Health, and the Administration for Industry and Commerce, and the Standardization Administration of the People's Republic of China (SAC). The large number of agencies with regulatory responsibilities in this area has been

3 The Agreement on the Application of Sanitary and Phytosanitary Measures of the WTO (the SPS Agreement) contains provisions to ensure transparency in the development and application of SPS measures. The provisions include the publication - or notification - of such measures on the WTO website to inform other members of potential trade impacts. 
subject to criticism as it has been suggested sometimes to lead to an uncoordinated and confusing system (Asian Development Bank, 2007). Other problems often cited include low levels of enforcement of standards and regulations by food safety officials and a lack of inspectors supervising an ever-increasing number of food producers (Broughton and Walker, 2010).

SAC is the agency responsible for approving and publishing Chinese standards and adopting international standards, including food standards. According to Wang Ping, the Executive Governor of Science and Technology Committee of the China National Institute of Standardization, standardization in SAC takes place in 450 national technical committees in which stakeholders from government agencies, industry and research organization participate. SAC nominates the participants, and the technical committees are jointly run by SAC and some ministries (Ping, 2010). SAC also represents Chinese interests in international organizations. China is actively involved in the Codex Alimentarius Commission (CAC), the organization responsible for setting international standards for food products. For instance, SAC hosts the CAC sector committees for pesticide studies and food additives (WHO, 2011). Setting food safety standards is a general priority of the Chinese government. In the Eleventh Five-year Plan of Standardization development, agriculture and food safety were named key areas for standardization activities, and the Chinese standardization strategy encourages the adoption of international standards (Ping et al., 2010).

China's accession to the WTO in 2001 and the signing of the Agreement on Technical Barriers to Trade (TBT Agreement) and the Agreement on Sanitary and Phytosanitary Measures (SPS Agreement) gave further incentives to harmonize domestic standards. Both Agreements incorporate international standards. According to Article 2.4 of the TBT Agreement and Article 3.1 of the SPS Agreement WTO, members are obliged to use international standards where they exist. Domestic standards that are harmonized to international standards are automatically presumed to comply with other obligations of the agreements and are immune from trade disputes in the WTO Dispute Settlement Body. China and other WTO members can decide not to base their domestic standards on international standards. In case a member implements standards considered highly protectionists, it must provide specific justifications for the deviation according to the SPS agreement ${ }^{4}$ (Du, 2010). Thus, the TBT Agreement and SPS Agreement do not mandate the use of international standards but provide strong incentives for China and other WTO members to harmonize their domestic standards.

Despite the incentives to adopt international standards, the number of Chinese standards based on international measures remains low compared to other countries. From the total number of standards in our database only $14 \%$ are based on international measures. In addition, China tends to use international

4 Article 2.4 of the TBT Agreement and Article 3.3 of the SPS Agreement. 
standards partially-70\% of all harmonized standards in our database are modified versions of international standards, but only $30 \%$ is identical to international standards. In the next section, we analyze empirically the impact of standardization and harmonization on Chinese food exports.

\section{Empirical model and results}

\section{Data sources and descriptive statistics}

In this section, we describe our dataset and provide descriptive statistics. Export volumes are compiled from the COMTRADE database at the Harmonized System (HS, 1992) and tariffs are compiled from the TRAINS data base. Consumption variables are computed from the Food and Agriculture Organization of the United Nations' statistical database FAOSTAT. ${ }^{5}$ Our dataset covers seven product groups which are a frequently a target of strict food standards and heavy regulation (Chen et al., 2008): meat (HS-02), fish (HS-03), vegetables (HS-07), cereals (HS-10)), milk (HS-0401 and HS-0402), tea (HS-0902), and sugar (HS-1701 and HS-1702).

Chinese exports in agricultural and food products are increasing. Between 1992 and 2008, total agricultural exports rose from 9.7 to 30.1 billion US\$. Exports in the seven product categories represent about $40 \%$ of Chinese agricultural exports, and went up from 5.1 billion US\$ in 1992 to 12.1 billion US\$ in 2008.

The evolution of Chinese exports in the seven product categories is shown in Figure 1. Exports seem to increasingly follow China's comparative advantage in labor-intensive products (Fang and Beghin, 2000). Labor-intensive products - such as vegetables and tea - register large growth rates especially after China's accession to the WTO in 2001. In contrast, exports of land-intensive products - such as sugar, cereal and meat-have increased to a lesser extent. In 2008, China's agriculture exports accounted for about $10 \%$ of all agriculture exports from lowand middle-income countries.

Data on mandatory and voluntary standards are compiled from the Standards Administration of the Peoples Republic of China (SAC), the Chinese official national standards body. ${ }^{6}$ Chinese standards developed in SAC are accessible through an online database: the SAC National Standards Query (SAC, 2011b). The database has been recently used in Mangelsdorf (2011). To ensure reliability and completeness, the standards have been cross checked with the 'Chinese Bulletin of Standards' (SAC, 2011a) and the German-Chinese Standards Portal (DIN and SAC, 2011). The Chinese National Standards Query provides information on the date the standard came into effect, the date the standard was withdrawn, or replaced by newer version. Each standard is classified according to the

6 SAC obtained legal recognition by the Chinese government through the Standardization Law of the People's Republic of China from 1988 (source: ISO, 2009). 
Figure 1. Chinese exports in agriculture and food products

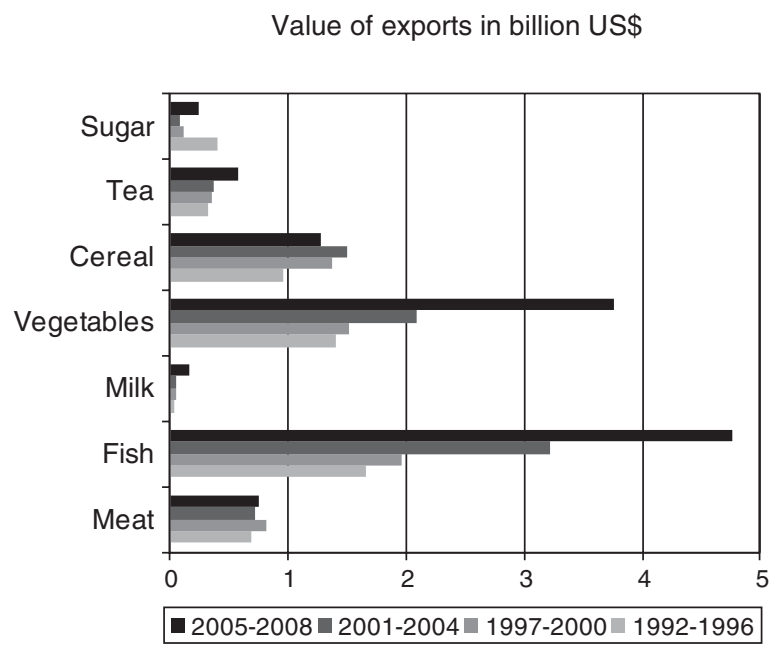

Source: COMTRADE Database, authors calculation

International Classification of Standards (ICS) nomenclature, which allows matching standards to trade data. The database allows differentiation between Chinese standards harmonized to international norms, such as Codex Alimentarius, and standards that are unique to China. ${ }^{7} \mathrm{~A}$ concordance table between the seven-digit ICS categories and the trade data in HS codes can be found in Table A.1 in the Appendix. The database allows us to construct four different standards variables according to two criteria: (i) mandatory vs. voluntary standards, and (ii) domestic vs. international harmonized standards.

Table 1 provides some examples to illustrate the different types of standards. The first example, the standard GB/T 19838-2005 for fish and fishery products is a voluntary domestic Chinese standard. It makes companies accountable for analyzing potential hazards regarding the product and establishes control points to ensure food safety (Caswell and Hooker, 1996). The standard GB 14939-1994 'Hygienic standard for canned fish' is a mandatory performance standard equivalent to the international Codex Standard 70. Besides process and performance standards, a number of standards are testing standards. For instance, GB/T 223882008 is a voluntary testing standard that determines the content of melamine, and GB/T 23376-2009 specifies testing methods for pesticide residuals in tea.

We construct a frequency measure for the four types of standards, which counts the number of standards directly linked to agricultural commodities. Frequency

7 SAC develops mandatory and voluntary standards. The prefix 'GB' indicates mandatory standards and voluntary standards are prefixed ' $\mathrm{GB} / \mathrm{T}$ '. 
Table 1. Examples of Chinese standards

\begin{tabular}{|c|c|c|c|c|}
\hline $\begin{array}{l}\text { Product } \\
\text { group }\end{array}$ & Standard & Standard name & $\begin{array}{c}\text { Adopted } \\
\text { international } \\
\text { standard }\end{array}$ & $\begin{array}{l}\text { Application } \\
\text { degree }\end{array}$ \\
\hline Fish & $\begin{array}{l}\text { GB/T } \\
19838-2005\end{array}$ & $\begin{array}{l}\text { Hazard Analysis and Critical } \\
\text { Control Point (HACCP) system } \\
\text { and guidelines for its application } \\
\text { to fish \& fishery products }\end{array}$ & - & - \\
\hline Fish & $\begin{array}{l}\text { GB } \\
14939-1994\end{array}$ & Hygienic standard for canned fish & CAC 70:1995 & NEQ \\
\hline Cereal & $\begin{array}{l}\text { GB } \\
2715-2005\end{array}$ & Hygienic standard for grains & - & - \\
\hline Meat & $\begin{array}{l}\text { GB } \\
19303-2003\end{array}$ & $\begin{array}{l}\text { Hygienic practice of cooked meat } \\
\text { and meat-products factory }\end{array}$ & $\begin{array}{l}\text { CAC/ } \\
\text { RCP13-1976 }\end{array}$ & MOD \\
\hline Milk & $\begin{array}{l}\mathrm{GB} / \mathrm{T} \\
22388-2008\end{array}$ & $\begin{array}{l}\text { Determination of melamine in raw } \\
\text { milk and dairy products }\end{array}$ & - & - \\
\hline Tea & $\begin{array}{l}\mathrm{GB} / \mathrm{T} \\
23376-2009\end{array}$ & $\begin{array}{l}\text { Determination of pesticides } \\
\text { residues in tea-GC/MS method }\end{array}$ & - & - \\
\hline Vegetables & $\begin{array}{l}\text { GB } \\
2714-2003\end{array}$ & $\begin{array}{l}\text { Hygienic standard for preserved } \\
\text { vegetables }\end{array}$ & - & - \\
\hline Sugar & $\begin{array}{l}\text { GB } \\
13104-2005\end{array}$ & Hygienic standard for sugars & CAC 212:1999 & NEQ \\
\hline
\end{tabular}

Source: Authors' calculations based on SAC National Standards Query.

measures or count variables are often used to measure the impact of standards and regulations on trade. The advantage of frequency measures is that they are relatively easy to construct. Yet, these measures may suffer from the so-called 'mixed bag' problem, where each standard regulating food safety may differ in the level of stringency and have a different impact on trade. For instance, the 'hygienicperformance' standards might have a larger effect on exports than the 'testing standards', or vice versa. Due to the absence of variables indicating the complexity or stringency of the standards, we believe that the number of standards represents a good proxy for the level of regulatory intensity in China and has been widely used in the literature estimating the impact of standards on trade (see for instance Swann et al., 1996; Blind and Jungmittag, 2005; Moenius, 2004, 2006; Portugal-Perez et al., 2010; Otsuki et al., 2001).

Figure 2 depicts the evolution of the number of standards in the seven Chinese food products. The stock of active standards is computed as the initial stock before 1992 plus the standards published each year minus withdrawn standards. The total number of standards increases over time. Voluntary standards increased substantially after China's WTO accession in 2001. The dotted lines in Figure 2 reveal that the share of mandatory harmonized international standards decreased from $10.4 \%$ in 1992 to $8.9 \%$ in 2008 , whereas the share of voluntary international harmonized standard increased from $9.8 \%$ in 1992 to $15.0 \%$ in 2008 . 
Figure 2. Stock of voluntary and mandatory Chinese food standards

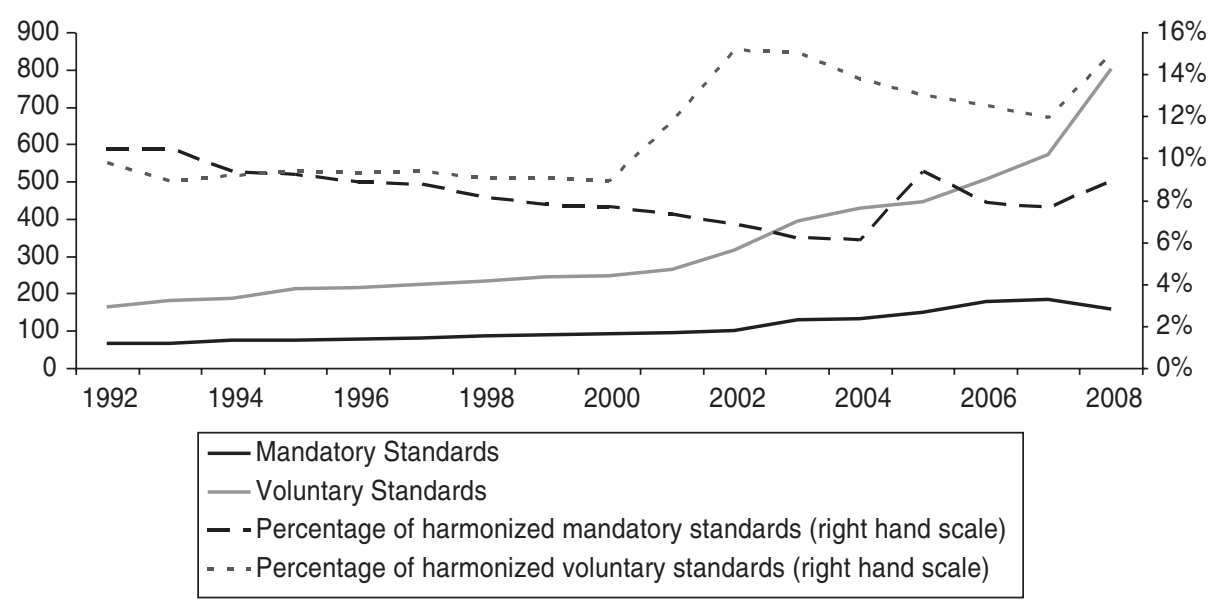

Regarding harmonization differences between product groups, Table 2 shows the percentage of Chinese standards that are harmonized to international norms or not. In 1992, for instance, $90.6 \%$ of Chinese standards for meat products are domestic standards and the remaining $9.4 \%$ are harmonized to international standards. China seems to be relying more on international standards, as the percentage of Chinese domestic standards is decreasing over time.

\section{Empirical strategy}

In this section, we present the empirical model used to estimate the impact of voluntary and mandatory standards on China's exports. The data allow differentiating between harmonized standards and Chinese domestic standards. We base our empirical model in an extended gravity model widely used in the trade literature (Anderson and van Wincoop, 2003; Anderson, 2011; Anderson and Yotov, 2011).

Similar to Moenius (2006), we focus on a country-specific stock of standards in the exporting country and a stock of international standards. Our specification differentiates between mandatory and voluntary standards, which in turn are differentiated between country-specific and international standards. Analogous to Anderson and Yotov (2011), we use domestic consumption as a proxy of sectoral output to capture the potential demand for Chinese agricultural and food products.

More specifically, we estimate the equation:

$$
\begin{aligned}
\ln X_{i k t}= & \beta_{0}+\beta_{1} \text { StMD }_{k t}+\beta_{2} \text { StMI }_{k t}+\beta_{3} S t V D_{k t} \\
& +\beta_{4} S t V I_{k t}+\beta_{5} \text { Tariff }_{i k t}+\beta_{6} \ln _{\text {Cons }} \text { ikt } \\
& +\delta_{i t}+\delta_{k t}+\delta_{i k}+\varepsilon_{i k t}
\end{aligned}
$$


Table 2. Percentage of Chinese domestic standards 1992-2008

\begin{tabular}{lrrrrr}
\hline \hline Product & 1992 & 1996 & 2000 & 2004 & 2008 \\
\hline Meat & 90.6 & 91.4 & 92.2 & 92.1 & 88.9 \\
Fish & 100.0 & 100.0 & 100.0 & 100.0 & 97.0 \\
Vegetables & 88.9 & 84.6 & 83.7 & 86.9 & 83.0 \\
Cereals & 100.0 & 98.9 & 99.0 & 98.6 & 88.7 \\
Milk & 73.6 & 75.4 & 75.4 & 75.0 & 80.5 \\
Tea & 100.0 & 100.0 & 100.0 & 75.0 & 74.3 \\
Sugar & 100.0 & 100.0 & 100.0 & 100.0 & 86.7 \\
\hline \hline
\end{tabular}

Source: Authors' calculations based on SAC National Standards Query.

where:

$X_{i k t}$ is the value of Chinese exports of product $k$ to country $i$ in year $t$ in dollars;

$S t M D_{k t}$ and $S t M I_{k t}$ are the stocks of mandatory purely domestic (non-harmonized) and international harmonized standards for product $k$ that are active in year $t$;

$S t M D_{k t}$ and $S t V I_{k t}$ are the stocks of voluntary domestic (non-harmonized) and international harmonized standards for product $k$ in year $t$;

Tariff $_{i k t}$ is the tariff imposed by country $i$ on Chinese exports of product $k$ in year $t$. $\ln _{\text {Cons }}{ }_{i k t}$ is the domestic consumption of product $k$ in country $i$ in year $t$, measured in dollars; ${ }^{8}$

$\delta_{i t}, \delta_{k t}, \delta_{i k}$ are interaction terms of importer-year dummies, product-year dummies and importer-product dummies;

$\varepsilon_{i k t}$ is an error term.

Three dummy interactions terms are incorporated in the baseline model. The interaction of importer and product dummies $\left(\delta_{i k}\right)$ control for invariable characteristics specific to the food sector in a given importer. Importer-year fixed effects $\left(\delta_{i t}\right)$ control for shocks experienced by an importer a given year, such as political shocks. Product-year fixed effects $\left(\delta_{k t}\right)$ control for shocks specific to world markets of a product in a given year. ${ }^{9}$

As noted before, previous empirical evidence shows that an increase in the number of standards in an exporting country is positively associated to exports, as information and signaling benefits seem to offset compliance costs. Indeed, standards in the exporting country reduce information asymmetries between

8 We computed the consumption of product $k$ in country $i$ and year $t$ as: $C_{i k t}=\left(S_{i k t}+M_{i k t}-X_{i k t}\right) \cdot P_{i k t}$, where $S_{i k t}$ the domestic supply of product $k$ in country $i$ in year $t$ in tonnes, $M_{i k t}\left[X_{i k t}\right]$ stands for import [exports] of product $k$ in country $i$ in year $t$ in tonnes, and $P_{i k t}$ is the import price of product $k$ in country $i$ in year $t$ in dollars.

9 A similar strategy of incorporating dummy interaction terms to control for unobserved effects is adopted by Harding and Javorcik (2011) and Ferro et al. (2011). 
Table 3. Descriptive statistics

\begin{tabular}{llcrc}
\hline \hline Model variable & & Observations & Mean & Standard deviation \\
\hline Bilateral exports & $\ln X_{i k t}$ & 7,646 & 5.98 & 2.99 \\
Mandatory international standards & $S t M I_{k t}$ & 7,646 & 1.12 & 1.50 \\
Mandatory domestic standards & $S t M D_{k t}$ & 7,646 & 14.42 & 9.36 \\
Voluntary international standards & $S t V I_{k t}$ & 7,646 & 4.77 & 6.22 \\
Voluntary domestic standards & $S t V D_{k t}$ & 7,646 & 42.32 & 37.03 \\
Consumption & $\ln$ Cons $_{i k t}$ & 6,848 & 19.82 & 2.88 \\
Tariff & Tariff & 6,089 & 0.13 & 0.16 \\
& & & & \\
\hline \hline
\end{tabular}

producers in China and importers abroad regarding quality and safety levels of food products. Therefore, we expect positive signs in the coefficients of Chinese standards variables with, a priori, a larger impact of mandatory standards compared to voluntary standards as compliance with the later is optional.

Internationally harmonized standards applied by Chinese producers are expected to have a positive impact on exports for two reasons. First, compliance with international standards can be a strong signal that Chinese producers meet safety and quality criteria that are widely recognized. Second, compared to national standards, the informational and signaling benefits of complying with internationally harmonized standards are expected to be larger than complying with national standards.

The coefficient of tariffs is expected to be negative. As a proxy of demand for each product group in each importing country, we include the total domestic consumption for each country and its sign is expected to be positive, as higher domestic demand is expected to increase the demand for imports from China.

\section{Results}

The estimation is carried out in a panel covering Chinese agricultural exports to 132 countries over the period 1992-2008. Table 3 summarizes descriptive statistics. Notice that there are fewer observations for consumption and tariffs, as data for these variables are sometimes not reported for some goods in an importing country. Yet, coefficient estimates for standards do not change significantly when these variables are excluded from regressions, as shown below.

Table 4 reports OLS estimates for our specification. Standard errors are clustered by product groups. Column 1 reports estimates from the baseline model (equation (1)). As consumption and tariff data have missing observations for some sectors in some countries, we exclude these variables from the baseline specification (column 2). In order to control for characteristics specific to products, importer, and years, we include the interaction of product-year dummies, importer-product dummies and importer-year dummies. Columns 1 and 2 include all three interaction variables and in columns 3 and 4 we only include the interaction of product-year 
Table 4. Baseline results

\begin{tabular}{|c|c|c|c|c|c|}
\hline Model variable & & $\begin{array}{c}1 \\
\text { base }\end{array}$ & $\begin{array}{c}2 \\
\text { base }\end{array}$ & $\begin{array}{c}3 \\
\text { base }\end{array}$ & $\begin{array}{c}4 \\
\text { base }\end{array}$ \\
\hline Mandatory international standards & $S t M I_{k t}$ & $\begin{array}{l}1.538 \\
{[0.203]^{* * *}}\end{array}$ & $\begin{array}{l}1.480 \\
{[0.217] * * *}\end{array}$ & $\begin{array}{l}0.497 \\
{[0.025] * * *}\end{array}$ & $\begin{array}{l}1.214 \\
{[0.462]^{* *}}\end{array}$ \\
\hline Mandatory domestic standards & $S t M D_{k t}$ & $\begin{array}{l}-0.047 \\
{[0.040]}\end{array}$ & $\begin{array}{l}-0.310 \\
{[0.103]^{* *}}\end{array}$ & $\begin{array}{l}-0.06 \\
{[0.005] * * *}\end{array}$ & $\begin{array}{l}-0.112 \\
{[0.038]^{* *}}\end{array}$ \\
\hline Voluntary international standards & $S t V I_{k t}$ & $\begin{array}{l}0.192 \\
{[0.056]^{* *}}\end{array}$ & $\begin{array}{l}0.115 \\
{[0.121]}\end{array}$ & $\begin{array}{l}0.021 \\
{[0.004] * * *}\end{array}$ & $\begin{array}{l}0.006 \\
{[0.021]}\end{array}$ \\
\hline Voluntary domestic standards & $S t V D_{k t}$ & $\begin{array}{l}0.002 \\
{[0.013]}\end{array}$ & $\begin{array}{l}0.035 \\
{[0.027]}\end{array}$ & $\begin{array}{l}0.003 \\
{[0.001]^{* *}}\end{array}$ & $\begin{array}{l}0.001 \\
{[0.004]}\end{array}$ \\
\hline Consumption $(\log )$ & $\ln$ Cons $_{i k t}$ & $\begin{array}{l}0.122 \\
{[0.046]^{* *}}\end{array}$ & & $\begin{array}{l}0.127 \\
{[0.022]^{* * * *}}\end{array}$ & \\
\hline Tariff & Tariff $_{i k t}$ & $\begin{array}{l}0.083 \\
{[0.655]}\end{array}$ & & $\begin{array}{l}-2.585 \\
{[1.408]}\end{array}$ & \\
\hline Constant & & $\begin{array}{l}-0.847 \\
{[0.630]}\end{array}$ & $\begin{array}{l}6.862 \\
{[1.269] * * *}\end{array}$ & $\begin{array}{l}2.834 \\
{[0.308]^{* * *}}\end{array}$ & $\begin{array}{l}2.661 \\
{[1.391]}\end{array}$ \\
\hline Observations & & 5,555 & 5,278 & 5,555 & 7,646 \\
\hline $\mathrm{R}^{2}$ & & 0.85 & 0.86 & 0.75 & 0.69 \\
\hline Importer-product dummies & & Yes & Yes & Yes & Yes \\
\hline Product-year dummies & & Yes & Yes & Yes & Yes \\
\hline Importer-year dummies & & Yes & Yes & No & No \\
\hline
\end{tabular}

Notes: The dependent variables are bilateral exports. Robust standard errors are clustered by product groups and are reported in brackets. The asterisks represent the level of significance: * significant at $10 \% ; *$ significant at $5 \% ; * *$ significant at $1 \%$.

dummies and importer-product dummies. The coefficient for mandatory internationally harmonized standards has the expected positive sign in all models. Voluntary internationally harmonized standards also have the expected positive sign but the coefficient is insignificant when excluding consumption and tariffs. Regarding the relative impact, internationally harmonized mandatory standards seem to have the largest impact on Chinese exports. The impact of domestic standards is less clear. Mandatory domestic standards exert a negative influence on exports in columns 2 to 4 but have no significant effect in column 1. Similarly, voluntary internationally harmonized standards are positively correlated with exports in column 3 but have no impact on exports in the other models. Thus, standards exert a positive impact on exports when they are harmonized with international norms.

Further robustness checks are reported in Table 5. We keep the three interaction terms from the baseline model in the next estimates. First, we aim to measure whether the effect of standards is different when the importer is a high-income country and constrain the sample to include only high-income importers. The results are qualitatively similar to the baseline model. As shown in columns 1 and 2, 
Table 5. Robustness checks

\begin{tabular}{|c|c|c|c|c|c|c|}
\hline Model variable & & $\begin{array}{c}1 \\
\text { High } \\
\text { income }\end{array}$ & $\begin{array}{c}2 \\
\text { High } \\
\text { income }\end{array}$ & $\begin{array}{c}3 \\
\text { 2-year } \\
\text { lagged } \\
\text { standards }\end{array}$ & $\begin{array}{c}4 \\
\text { 3-year } \\
\text { lagged } \\
\text { standards }\end{array}$ & $\begin{array}{c}5 \\
\\
\text { ET- } \\
\text { Tobit }\end{array}$ \\
\hline $\begin{array}{l}\text { Mandatory } \\
\text { international } \\
\text { standards }\end{array}$ & $S t M I_{k t}$ & $\begin{array}{l}1.313 \\
{[0.317]^{* * *}}\end{array}$ & $\begin{array}{l}1.527 \\
{[0.157]^{* * *}}\end{array}$ & & & $\begin{array}{l}0.640 \\
{[0.090]^{* * * *}}\end{array}$ \\
\hline $\begin{array}{l}\text { Mandatory } \\
\text { domestic } \\
\text { standards }\end{array}$ & $S t M D_{k t}$ & $\begin{array}{l}-0.578 \\
{[0.089]^{* * *}}\end{array}$ & $\begin{array}{l}-0.276 \\
{[0.071]^{* * *}}\end{array}$ & & & $\begin{array}{l}0.030 \\
{[0.010] * * *}\end{array}$ \\
\hline $\begin{array}{l}\text { Voluntary } \\
\text { international } \\
\text { standards }\end{array}$ & $S t V I_{k t}$ & $\begin{array}{l}-0.430 \\
{[0.070]^{* * *}}\end{array}$ & $\begin{array}{l}0.053 \\
{[0.150]}\end{array}$ & & & $\begin{array}{l}0.020 \\
{[0.010]^{* * *}}\end{array}$ \\
\hline $\begin{array}{l}\text { Voluntary } \\
\text { domestic } \\
\text { standards }\end{array}$ & $S t V D_{k t}$ & $\begin{array}{l}0.166 \\
{[0.017]^{* * *}}\end{array}$ & $\begin{array}{l}0.024 \\
{[0.018]}\end{array}$ & & & $\begin{array}{l}0.001 \\
{[0.000]}\end{array}$ \\
\hline Consumption & $\ln$ Cons $_{i k t}$ & $\begin{array}{l}0.390 \\
{[0.170]^{*}}\end{array}$ & & $\begin{array}{l}0.071 \\
{[0.069]}\end{array}$ & $\begin{array}{l}0.068 \\
{[0.062]}\end{array}$ & $\begin{array}{l}0.070 \\
{[0.030]^{* * * *}}\end{array}$ \\
\hline Tariff & Tariff $_{i k i}$ & $\begin{array}{l}3.865 \\
{[3.497]}\end{array}$ & & $\begin{array}{l}0.401 \\
{[0.800]}\end{array}$ & $\begin{array}{l}-0.039 \\
{[0.777]}\end{array}$ & $\begin{array}{l}-2.940 \\
{[0.300]^{* * *}}\end{array}$ \\
\hline $\begin{array}{l}\text { Mandatory } \\
\text { international } \\
\text { standards (lagged) }\end{array}$ & $S t M I_{k t-2}$ & & & $\begin{array}{l}0.868 \\
{[0.134]^{* * * *}}\end{array}$ & & \\
\hline $\begin{array}{l}\text { Mandatory domestic } \\
\text { standards (lagged) }\end{array}$ & $S t M D_{k t-2}$ & & & $\begin{array}{l}0.013 \\
{[0.046]}\end{array}$ & & \\
\hline $\begin{array}{l}\text { Voluntary } \\
\text { international } \\
\text { standards (lagged) }\end{array}$ & $S t V I_{k t-2}$ & & & $\begin{array}{l}0.552 \\
{[0.072]^{* * * *}}\end{array}$ & & \\
\hline $\begin{array}{l}\text { Voluntary domestic } \\
\text { standards (lagged) }\end{array}$ & $S t V D_{k t-2}$ & & & $\begin{array}{l}-0.087 \\
{[0.008]^{* * *}}\end{array}$ & & \\
\hline $\begin{array}{l}\text { Mandatory } \\
\text { international } \\
\text { standards (lagged) }\end{array}$ & $S t M I_{k t-2}$ & & & & $\begin{array}{l}1.381 \\
{[0.125]^{* * *}}\end{array}$ & \\
\hline $\begin{array}{l}\text { Mandatory domestic } \\
\text { standards (lagged) }\end{array}$ & $S t M D_{k t-3}$ & & & & $\begin{array}{l}-0.477 \\
{[0.051]^{* * *}}\end{array}$ & \\
\hline $\begin{array}{l}\text { Voluntary } \\
\text { international } \\
\text { standards (lagged) }\end{array}$ & $S t V I_{k t-3}$ & & & & $\begin{array}{l}0.039 \\
{[0.086]}\end{array}$ & \\
\hline $\begin{array}{l}\text { Voluntary domestic } \\
\text { standards (lagged) }\end{array}$ & $S t V D_{k t-3}$ & & & & $\begin{array}{l}0.011 \\
{[0.017]}\end{array}$ & \\
\hline Constant & & $\begin{array}{l}-6.979 \\
{[4.476]}\end{array}$ & $\begin{array}{l}2.483 \\
{[0.668] * * *}\end{array}$ & $\begin{array}{l}6.862 \\
{[1.269] * * *}\end{array}$ & $\begin{array}{l}7.846 \\
{[2.034] * * *}\end{array}$ & $\begin{array}{l}0.170 \\
{[1.15]}\end{array}$ \\
\hline Observations & & 2,073 & 2,579 & 5,278 & 5,076 & 10,752 \\
\hline $\mathrm{R}^{2}$ & & 0.90 & 0.87 & 0.86 & 0.87 & \\
\hline
\end{tabular}

Notes: The dependent variables are bilateral exports. Robust standard errors are clustered by product groups and are reported in brackets. All estimates include importer-year dummies, product-year dummies and importer-product dummies.

The asterisks represent the level of significance: * significant at $10 \%$; * significant at $5 \%$; $* *$ significant at $1 \%$. 
the impact of mandatory standards is positive and significant for high-income importers, whereas the effect of voluntary harmonized standards is much smaller and only significant with the inclusion of consumption and tariffs. Domestic mandatory standards clearly exert a negative influence on exports and the effect of voluntary standards is positive but smaller than the effect of harmonized standards. The results suggest that high-income importers value harmonized standards - mandatory in particular - as more important than domestic standards.

Standardization could also be influenced by exporters in a particular sector through lobbying, potentially leading to endogeneity of standards due to reverse causality. Previous empirical literature on standards acknowledges the potential problem of endogeneity and the difficulty of finding a good instrument to circumvent it. However, in the case of Chinese standards, it is unlikely that they are set in response to unexpected surges in food imports demand from a single country in a single year, given the complexity and the high number of Chinese agencies involved in making standards. Moreover, standards generation is a timeconsuming process. It requires the coordination of preferences from various interests groups. In international standardization, the time between the first proposition of a new standard and the final publication can take more than five years (Blind and Jungmittag, 2005). In China, the average time to for generating a new standard is 4.7 years (Ping, 2010). Yet, as another robustness check, we include alternately in our regressions two-year and three-year lagged standards variables and report estimates in columns 3 and 4. Qualitatively, results are the same, standards exert a positive impact on exports, with the highest effect for mandatory harmonized standards. ${ }^{10}$

Finally, we run the threshold-Tobit type of model applied by Eaton-Tamura (1994) among others, in the context of gravity models. Indeed, Eaton and Tamura (1994) proposed to estimate a variation of the Tobit model in which the dependent variable is $\ln \left(a v+X_{i k t}\right)$, where $a v$ is a parameter to be added to exports before the $\log$, and the maximum likelihood (ML) function is modified to endogenize the choice of the $a v$ parameter. Then the ML estimator includes an estimate of the value of $a v$ among the set of estimates which means that the dependent variable will be censored at the value $\ln (a v)$ (see Eaton and Tamura (1994) or de Melo and Portugal-Perez (2012) for more details on the estimator). Column 5 in Table 5 reports estimates of the threshold-Tobit. As the estimated value for $a v$ is close to zero (av $=0000458)$, estimates are very close to the baseline estimates using OLS. Yet, we keep OLS estimates as our baseline estimates for the sake of parsimony.

10 As an additional robustness check, we perform a Durbin-Wu-Hausman test of endogeneity of our standard variables in on our baseline model, using the ivregress command in STATA. Accordingly, we instrument the standards variables with one-lagged standards variables, and the test results show that we cannot reject the null hypothesis for exogeneity at the $1 \%$ level. Estimates of the IV regression are not reported here but can be made available upon request. 
Table 6 reports estimates for the seven product groups. The impact of standards seems to vary to some extent but the impact on exports is positive. Mandatory international standards for fish, vegetables, cereals, and tea were excluded from the model because of mulitcollinearity with dummy variables. In the other estimates, however, the variable shows the expected positive sign and is statistically significant for sugar. Domestic mandatory standards are also positive and significant for most product groups. As in the baseline model, the marginal effect for mandatory international standards is larger than the impact of domestic mandatory standards. In other words, one additional international standard leads to more exports than one additional domestic standard. The impact of voluntary standards is less clear. Domestic voluntary standards are positively correlated with Chinese exports for most product groups but the impact of voluntary international standards is ambiguous. The impact of international standards is positive and highly significant for vegetables and sugar but negative and significant for tea and fish. A plausible explanation for the low impact of voluntary standards is the lack of implementation by Chinese farmers and food producers. Although there is no data on the implementation of voluntary standards, the China Statistic Yearbook of Certification and Accreditation (cited in Jin et al., 2008) shows that in 2005 the number of voluntary food safety standards for hazard analysis and critical control point (HACCP) was implemented by only $21.9 \%$ of the food industry. Assuming that this figure is representative for implementation of voluntary standards in general, the low impact of voluntary standards in our model can be explained by the low implementation of voluntary standards.

\section{Conclusion}

The paper provides the first empirical evidence on the impact of Chinese standards for the export of agricultural goods. Whereas past literature on the trade impact of standards for developing countries has focused on standardization in the importing (developed) country, we argue that the effect of standards in the exporting country has to be taken into account. In particular, we show that standards harmonization in China has a positive effect for China's exports success.

Our results can be summarized as follows. First, based on new data, our results confirm the trade-enhancing potential of standards, outlined in previous studies (see for instance Swann (2010)). We find that a larger stock of standards in China is associated with expanding exports.

Second, we can show that the push effect of standards is larger when they are based on international standards such as Codex Alimentarius. Our estimation suggests that one additional internationally harmonized standard in China is associated with an increase in agricultural exports ranging between $0.5 \%$ and $1.54 \%$.

Third, the effect on trade of standards is different for voluntary and mandatory standards. The impact of mandatory standards is generally positive and statistically 
Table 6. Results for products

\begin{tabular}{|c|c|c|c|c|c|c|c|c|}
\hline Model variable & & $\begin{array}{c}1 \\
\text { Meat }\end{array}$ & $\begin{array}{c}2 \\
\text { Fish }\end{array}$ & $\begin{array}{c}3 \\
\text { Vegetables }\end{array}$ & $\begin{array}{c}4 \\
\text { Cereals }\end{array}$ & $\begin{array}{c}5 \\
\text { Milk }\end{array}$ & $\begin{array}{c}6 \\
\text { Tea }\end{array}$ & $\begin{array}{c}7 \\
\text { Sugar }\end{array}$ \\
\hline Mandatory international standards & $S t M I_{i k t}$ & $\begin{array}{c}0.165 \\
{[0.246]}\end{array}$ & $-\dagger$ & $-\dagger$ & $-\dagger$ & $\begin{array}{c}0.468 \\
{[0.505]}\end{array}$ & $-\dagger$ & $\begin{array}{l}3.480 \\
{[0.602] * * *}\end{array}$ \\
\hline Mandatory domestic standards & $S t M D_{i k t}$ & $\begin{array}{c}0.001 \\
{[0.057]}\end{array}$ & $\begin{array}{l}0.055 \\
{[0.015]^{* * *}}\end{array}$ & $\begin{array}{c}0.016 \\
{[0.017]}\end{array}$ & $\begin{array}{c}-0.185 \\
{[0.102]^{*}}\end{array}$ & $\begin{array}{c}0.213 \\
{[0.169]}\end{array}$ & $\begin{array}{c}0.013 \\
{[0.016]}\end{array}$ & $\begin{array}{c}0.191 \\
{[0.342]}\end{array}$ \\
\hline Voluntary international standards & $S t V I_{i k t}$ & $\begin{array}{c}0.049 \\
{[0.064]}\end{array}$ & $\begin{array}{l}-0.993 \\
{[0.191]^{* * *}}\end{array}$ & $\begin{array}{c}0.041 \\
{[0.017]^{* *}}\end{array}$ & $\begin{array}{c}-0.097 \\
{[0.076]}\end{array}$ & $\begin{array}{c}-0.862 \\
{[0.860]}\end{array}$ & $\begin{array}{l}-0.115 \\
{[0.044]^{* * *}}\end{array}$ & $-\dagger$ \\
\hline Voluntary domestic standards & $S t V D_{i k t}$ & $\begin{array}{c}-0.003 \\
{[0.014]}\end{array}$ & $\begin{array}{l}0.060 \\
{[0.010]^{* * *}}\end{array}$ & $\begin{array}{l}0.020 \\
{[0.006]^{* * *}}\end{array}$ & $\begin{array}{c}0.045 \\
{[0.025]^{*}}\end{array}$ & $\begin{array}{c}0.101 \\
{[0.097]}\end{array}$ & $\begin{array}{l}0.072 \\
{[0.017]^{* * *}}\end{array}$ & $\begin{array}{c}-0.162 \\
{[0.099]}\end{array}$ \\
\hline Consumption & $\ln$ Cons $_{i k t}$ & $\begin{array}{r}-0.259 \\
{[0.387]}\end{array}$ & $\begin{array}{c}0.161 \\
{[0.167]}\end{array}$ & $\begin{array}{c}0.189 \\
{[0.209]}\end{array}$ & $\begin{array}{c}0.025 \\
{[0.398]}\end{array}$ & $\begin{array}{c}0.150 \\
{[0.119]}\end{array}$ & $\begin{array}{c}-0.051 \\
{[0.053]}\end{array}$ & $\begin{array}{c}0.103 \\
{[0.092]}\end{array}$ \\
\hline Tariff & Tariff $_{i k t}$ & $\begin{array}{c}0.035 \\
{[0.928]}\end{array}$ & $\begin{array}{c}0.432 \\
{[1.183]}\end{array}$ & $\begin{array}{r}-0.425 \\
{[0.754]}\end{array}$ & $\begin{array}{l}-4.397 \\
{[1.410]^{* * * *}}\end{array}$ & $\begin{array}{c}-7.696 \\
{[4.156]^{*}}\end{array}$ & $\begin{array}{c}0.495 \\
{[0.473]}\end{array}$ & $\begin{array}{c}-0.213 \\
{[0.870]}\end{array}$ \\
\hline Constant & & $\begin{array}{c}7.442 \\
{[7.794]}\end{array}$ & $\begin{array}{c}-4.786 \\
{[3.043]}\end{array}$ & $\begin{array}{c}-2.839 \\
{[2.996]}\end{array}$ & $\begin{array}{c}5.001 \\
{[6.308]}\end{array}$ & $\begin{array}{c}15.792 \\
{[12.681]}\end{array}$ & $\begin{array}{l}6.106 \\
{[0.951]^{* * * *}}\end{array}$ & $\begin{array}{c}-0.986 \\
{[2.756]}\end{array}$ \\
\hline Observations & & 644 & 768 & 1209 & 784 & 243 & 1,006 & 901 \\
\hline $\mathrm{R}^{2}$ & & 0.68 & 0.84 & 0.84 & 0.69 & 0.67 & 0.88 & 0.70 \\
\hline
\end{tabular}

Notes: The dependent variables are bilateral exports. The asterisks represent the level of significance: " significant at $10 \%$; $* *$ significant at $5 \%$; *** significant at $1 \%$. Standard errors in brackets. All estimates include importer dummies and time dummies. $†$ The variable for mandatory international harmonized standards were dropped because of multicollinearity with dummy variables. 
significant for both purely domestic and international harmonized standards. The trade impact for voluntary standards is less clear. Although voluntary domestic standards have a positive impact on Chinese exports in most model specifications, the impact is either smaller or statistically not significant compared to mandatory standards. Among other factors, this may be due to mandatory regulations affecting many more aspects of food products along supply chains.

As we explain, the positive impact of standards is also due to its contribution to reduce information asymmetries. Standards - whether voluntary or mandatory increase the transparency of the food products by providing information such as maximum levels of pesticides to consumers. The impact on trade of international harmonized standards is larger than the impact of purely domestic standards, and this is particularly true for international harmonized mandatory standards. It can be explained with the signaling effect of standards regarding quality and food safety. Producers have an incentive to apply standards as they are a signal for the producers' investment in high-quality products. In the case of Chinese food products, international mandatory standards seem to have a larger signaling effect than purely domestic standards. Foreign customers seem to acknowledge the producers decision to invest in compliance with international standards.

We conclude the paper by providing the following policy suggestions. First, our results show a larger trade impact of harmonized standards compared to purely domestic standards. Chinese authorities should increase their efforts to harmonize domestic food standards. This holds not only for mandatory but also for voluntary standards. Harmonization of food standards is in particular important when Chinese producers want to access foreign markets, especially in developed countries. Second, China and other developing countries should continue to expand participation in international standards setting organizations, such as Codex Alimentarius Commission. Participation in international organizations allows Chinese stakeholders to include specific national preferences in international norms and may facilitate adoption at the national level. Third, under the WTO, TBT, and SPS Agreements member countries should use international standards where they exist but are free to set domestic standards to fulfill regulatory objectives such as food safety. When developing domestic standards, authorities in emerging economies can leverage incentives in WTO obligations to expand trade-to the benefit of both their countries and the global consumers.

\section{References}

Anderson, J. E. (2011), 'The Specific Factors Continuum Model, with Implications for Globalization and Income Risk', Journal of International Economics, 85(2): 74-185.

Anderson, J. E. and E. van Wincoop (2003), 'Gravity with Gravitas: A Solution to the Border Puzzle', The American Economic Review, 93(1): 170-192.

Anderson, J.E. and Y.V. Yotov (2011), 'Terms of Trade and Global Efficiency Effects of Free Trade Agreements, 1990-2002', National Bureau of Economic Research Working Paper No. 17003. 
Asian Development Bank (2007), 'ADB Observations and Suggestions Policy Note: Suggestions on Strengthening Food Safety in the PRC', Asian Development Bank.

Bai, L., C. Ma, Y. Yang, S. Zhao, and S. Gong (2007), 'Implementation of HACCP System in China: A Survey of Food Enterprises Involved', Food Control, 18(9): 1108-1112.

Blind, Knut and A. Jungmittag (2005), 'Trade and the Impact of Innovations and Standards: The Case of Germany and the UK', Applied Economics, 37(12): 1385-1398.

Broughton, E. I. and D. G. Walker (2010), 'Policies and Practices for Aquaculture Food Safety in China', Food Policy, 35(5): 471-478.

Caswell, J. A. and N. H. Hooker (1996), 'HACCP as an International Trade Standard', American Journal of Agricultural Economics, 78(3): 775-779.

Chen, C., J. Yang, and C. Findlay (2008), 'Measuring the Effect of Food Safety Standards on China's Agricultural Exports', Review of World Economics, 144(1): 83-106.

Czubala, W., B. Shepherd, and J. S. Wilson (2007), 'Help or Hindrance? The Impact of Harmonized Standards on African Exports', Policy Research Working Paper 4400, The World Bank Development Research Group Trade Team.

de Melo, J. and A. Portugal-Perez (2012), 'Preferential Market Access Design: Evidence and Lessons from African Apparel Exports to the US and to the EU', World Bank Policy Research Working Paper, forthcoming.

DIN and SAC (2011), 'Deutsches Institut für Normung (DIN) and Standards Administration of China (SAC): German-China Standards Information Portal', http://cn-e.standards-portal.de.

Du, M. M. (2010), 'Reducing Product Standards Heterogeneity through International Standards in the WTO: How Far across the River?', Journal of World Trade, 44(2): 295-318.

Eaton, J. and A. Tamura (1994), 'Bilateralism and Regionalism in Japanese and US Trade and Direct Foreign Investment Patterns', Journal of the Japanese and International Economies, 8(4): 478-510.

Fang, C. and J. C. Beghin (2000), 'Food Self-Sufficiency, Comparative Advantage, and Agricultural Trade: A Policy Analysis Matrix for Chinese Agriculture’, Staff General Research Papers 1627, Department of Economics, Iowa State University.

Ferro, E., A. Portugal-Perez, and J.S. Wilson (2011), 'Aid to the Services Sector Does It Affect Manufacturing Exports?', World Bank Policy Research Working Paper 5728, World Bank, Washington, DC.

Gale, F. and J. C. Buzby (2009), 'Imports from China and Food Safety Issues', United States Department of Agriculture Economic Information Bulletin No. 52.

Harding, T. and B.S. Javorcik (2011), 'Roll Out the Red Carpet and They Will Come: Investment Promotion and FDI Inflows', The Economic Journal, 121: 1445-1476.

Henson, S. (2004), 'Standards and Trade: An Overview', University of Guelph, Ontario, Canada.

Henson, S. and S. Jaffee (2008), 'Understanding Developing Country Strategic Responses to the Enhancement of Food Safety Standards', World Economy, 31(4): 548-568.

Hudson, J. and P. Jones (2003), 'International Trade in 'Quality Goods?: Signalling Problems for Developing Countries', Journal of International Development, 15(8): 999-1013.

ISO (2009), 'ISO Members', International Organization for Standardization, Geneva.

Jin, S., J. Zhou, and J. Ye (2008), 'Adoption of HACCP System in the Chinese Food Industry: A Comparative Analysis', Food Control, 19(8): 823-828.

Leland, H. E. (1979), 'Quacks, Lemons, and Licensing - Theory of Minimum Quality Standards', Journal of Political Economy, 87(6): 1328-1346.

Mangelsdorf, A. (2011), 'The Role of Technical Standards for Trade between China and the European Union', Technology Analysis and Strategic Management, 23(7): 725-743.

Maskus, K., T. Otsuki, and J. Wilson (2004), 'The Costs of Complying with Foreign Product Standards for Firms in Developing Countries: An Econometric Study', World Bank, Washington, DC.

Moenius, J. (2004), 'Information Versus Product Adaptation: The Role of Standards in Trade', International Business and Markets Research Center Working Paper, Northwestern University, Evanston.

Moenius, J. (2006), 'The Good, the Bad and the Ambiguous: Standards and Trade in Agricultural Products', IATRC Summer Symposium, 28-30 May, Bonn. 
Otsuki, T., J. S. Wilson, and M. Sewadeh (2001), 'What Price Precaution? European Harmonisation of Aflatoxin Regulations and African Groundnut Exports', European Review of Agricultural Economics, 28(3): 263-283.

Ping, W. (2010), 'On Standardization in China', http://www.talkstandards.com/on-standardization-inchina.

Ping, W., W. Yiyi, and J. Hill (2010), 'Standardization Strategy of China - Achievements and Challenge': East-West Center Working Paper, Economics Series No. 07.

Portugal-Perez, Alberto, J.D. Reyes, and J.S. Wilson (2010), 'Beyond the Information Technology Agreement: Harmonization of Standards and Trade in Electronics', The World Economy, 33(12): 1870-1897.

SAC (2011a), 'Standards Administration of China (SAC): Bulletin of National Standards, Various Issues', http://www.sac.gov.cn/sac_en/BulletinofStandards.

_ (2011b), 'Standards Administration of China (SAC): National Standards Query', http://www.sac.gov. cn/SACSearch/outlinetemplet/gjbzcx_en.jsp.

Songa, H. and K. Chen (2010), 'Trade Effects and Compliance Costs of Food Safety Regulations: The Case of China', Agriculture and Agricultural Science Procedia, 1: 429-438.

Swann, G. M. P., P. Temple, and M. Shurmer (1996), 'Standards and Trade Performance: The British Experience', Economic Journal, 106(438): 1297-1313.

Swann, G. P. (2010), International Standards and Trade: A Review of the Empirical Literature, OECD Trade Policy Working Papers, No. 97, OECD Publishing.

WHO (2011), 'World Health Organization: Structure of the Codex Alimentarius Commission (CAC)', http://www.who.int/foodsafety/codex/general_info/en/index3.html.

Wilson, J. S., T. Otsuki, and B. Majumdsar (2003), 'Balancing Food Safety and Risk: Do Drug Residue Limits Affect International Trade in Beef?', Journal of International Trade and Economic Development, 12(4): 377-402.

Yue, N., H. Kuang, L. Sun, L. Wu, and C. Xu (2010), 'An Empirical Analysis of the Impact of EU's New Food Safety Standards on China's Tea Exports', International Journal of Food Science and Technology, 45: 745-750.

\section{Appendix}

Table A.1 Concordance table between harmonized commodity description and coding system (HS 1992) and International Classification of Standards (ICS)

\begin{tabular}{|c|c|c|c|}
\hline $\begin{array}{l}\text { Product } \\
\text { name }\end{array}$ & $\begin{array}{l}\text { HS } 1992 \\
\text { chapter }\end{array}$ & $\begin{array}{c}\text { International Classification } \\
\text { of Standards Title }\end{array}$ & $\begin{array}{c}\text { International Classification } \\
\text { of Standards (ICS) Code }\end{array}$ \\
\hline Meat & 02 & Meat and meat products & 67.120 .10 \\
\hline Fish & 03 & Fish and fishery products & 67.120 .30 \\
\hline Vegetables & 07 & $\begin{array}{l}\text { Vegetables and derived } \\
\text { products }\end{array}$ & 67.080 .20 \\
\hline Cereals & 10 & $\begin{array}{l}\text { Cereals, pulses and derived } \\
\text { products }\end{array}$ & 67.060 \\
\hline Milk & 0401,0402 & $\begin{array}{l}\text { Milk and processed milk } \\
\text { products }\end{array}$ & 67.100 .10 \\
\hline Tea & 0902 & Tea & 67.140 .10 \\
\hline Sugar & 1701,1702 & Sugar and sugar products & 67.180 .10 \\
\hline
\end{tabular}

